\title{
Future Risk Analysis for Bank Investments using PROMETHEE *
}

\author{
JEAN BAPTISTE RAKOTOARIVELO ${ }^{\text {a,b }}$, PASCALE ZARATÉ ${ }^{\text {b }}$, D. MARC KILGOUR ${ }^{\text {c }}$ \\ a Université de Toamasina, Sis 5, rue Bir Hakeim, Camp Manguier BP : 591 - Toamasina 501 - \\ Madagascar.E-mail: Jean-Baptiste.Rakotoarivelo@irit.fr \\ b IRIT - Toulouse Capitole University , 2 rue du Doyen Gabriel Marty 31042 Toulouse Cedex 9, \\ France.E-mail: Pascale.Zarate@irit.fr \\ $b$ Wilfrid Laurier University - 75 University Avenue West, Waterloo, Ontario N2L 3C5, Canada. E- \\ mail: mkilgour@wlu.ca
}

\begin{abstract}
Professional management of financial activities requires a good understanding of the inherent future risks of those activities. Despite the use of complex models for this purpose, significant risks often remain under-appreciated. This article develops techniques that will assist banking institutions at understanding the risks involved in micro-finance and related operations. The analysis is carried out by identifying financial operations that are typical of banking on a smaller scale, such as investing and extending credit, and the types of risk inherent in these activities, which are then grouped into the categories of operational risk, financial risk, management risk, and external risk. Analysis is conducted using the PROMETHEE multi-criteria decision methodology. Based on our new approach to risk analysis, many institutions will improve the management of their financial operations, including micro-finance.
\end{abstract}

Keywords: MCDM, Risk Analysis, Bank Investment, PROMETHEE.

\section{Análisis del Riesgo Futuro para Inversiones Bancarias utilizando PROMETHEE}

\section{RESUMEN}

La gestión profesional de las actividades financieras requiere una buena comprensión de los riesgos futuros inherentes a esas actividades. A pesar del uso de modelos complejos para este propósito, hay riesgos significativos que a menudo siguen siendo poco apreciados. Este artículo desarrolla técnicas que ayudarán a las instituciones bancarias a comprender los riesgos que conlleva la microfinanciación y las operaciones relacionadas. El análisis se lleva a cabo identificando las operaciones financieras típicas de la banca al por menor, como la inversión y la extensión del crédito, y los tipos de riesgo inherentes a estas actividades, que se agrupan en las categorías de riesgo operativo, riesgo financiero, riesgo de gestión y riesgo externo. El análisis se lleva a cabo utilizando la metodología multicriterio PROMETHEE. Conforme a nuestro nuevo enfoque del análisis de riesgos, muchas instituciones mejorarán la administración de sus operaciones financieras, incluidas las microfinanzas.

Palabras clave: Decisión Multicriterio, Análisis de Riesgos, Inversiones Bancarías, PROMETHEE.

JEL Classification: C02, C18, C44, C54, C65, D72, D83

\footnotetext{
${ }^{*}$ The authors would like to thank the CIMI Excellence Laboratory, Toulouse, France, for inviting Marc Kilgour on a Scientific Expert position during the period May-June 2016.
}

Artículo recibido en octubre de 2017 y aceptado en diciembre de 2017

Artículo disponible en versión electrónica en la página www.revista-eea.net, ref. ə-36117 


\section{INTRODUCTION}

Our goal is to analyse future risks faced by financial institutions, including specifically credit institutions that are engaged in micro-finance. Their activities, mainly collecting deposits and distributing credit, impact most of the population in developing countries, as well as the poor in developed countries. Our work is based on the use of the Multi-Criteria methodology PROMETHEE to analyse the risks for offering finance or investing, and depends on a specification of risks. Our objective is to support decision makers in financial institutions by clarifying the nature of the risks they face. To achieve this objective we combine the use of PROMETHEE with the Analytic Hierarchy Process (AHP) methodology. We firstly analyse the literature in order to model the problem. This first model is analysed with the AHP methodology based on the preference of the authors. These preferences are possible with a huge literature review. The first results are then used in the PROMETHEE methodology. The final results are presented in several manners (graphs, tables) useful for decision makers. The final results can support decision makers to rank several alternatives in order to deal with risks.

The risks faced by financial institutions depend on their economic activities and the environment in which they operate. Based on a literature review, we defined four different categories of risk, operational risk, financial risk, counterparty risk, and external risk [1] [2]. These four categories were then subdivided into 19 sub-criteria, as shown in Table 1. A large analysis of the literature was done and this table is as much as possible comprehensive.

Table 1

Different types of risks under study

\begin{tabular}{|l|l|l|l|}
\hline \multicolumn{1}{|c|}{ Operational risk } & Financial risk management & \multicolumn{1}{|c|}{ Counterparty risk } & \multicolumn{1}{c|}{ External risk } \\
\hline Risk of fraud & Currency risk & Liquidity risk & Country risk \\
Risk of Hold-up & Credit risk & Interest rate risk & Risk guarantee \\
Information risk & Risk Insider & Market risk & Concentration risk \\
Generic risk & Legal and regulatory risk & Solvency risk & Risk of recovery \\
Legal risk & Underwriting risk & & Risk of exposure \\
\hline
\end{tabular}

Source: Own elaboration.

The hierarchical structure defining the problem, given in Figure 1, clarifies the issues and shows the contribution of each element to the final decision. Eight alternatives, representing various financial operations, are shown on the right side of Figure 1. The criteria and sub-criteria are the elements that should influence the choice of alternative. At this step the goal is to find the links among the criteria, the sub-criteria, and the alternatives.

The hierarchical structure includes four levels. Level 0 is the global objective, level 1 the criteria by which achievement of the global objective is assessed, level 
2 the sub-criteria of which the criteria are composed, and level 3 the alternatives that may be selected. In Figure 1,

Level 0 represents the aim to select a project from the set of all alternatives.

Level 1 represents the criteria for this analysis,

$$
\begin{aligned}
& \mathrm{C}_{1}=\text { operational risk } \\
& \mathrm{C}_{2}=\text { financial risk management } \\
& \mathrm{C}_{3}=\text { counterparty risk } \\
& \mathrm{C}_{4}=\text { external risks. }
\end{aligned}
$$

Level 2 includes 19 sub-criteria, called SC1, SC2, .., SC19.

Level 3 includes 8 alternatives, called ALT1, ALT 2, ..., ALT 9.

Figure 1

Complete graphical representation

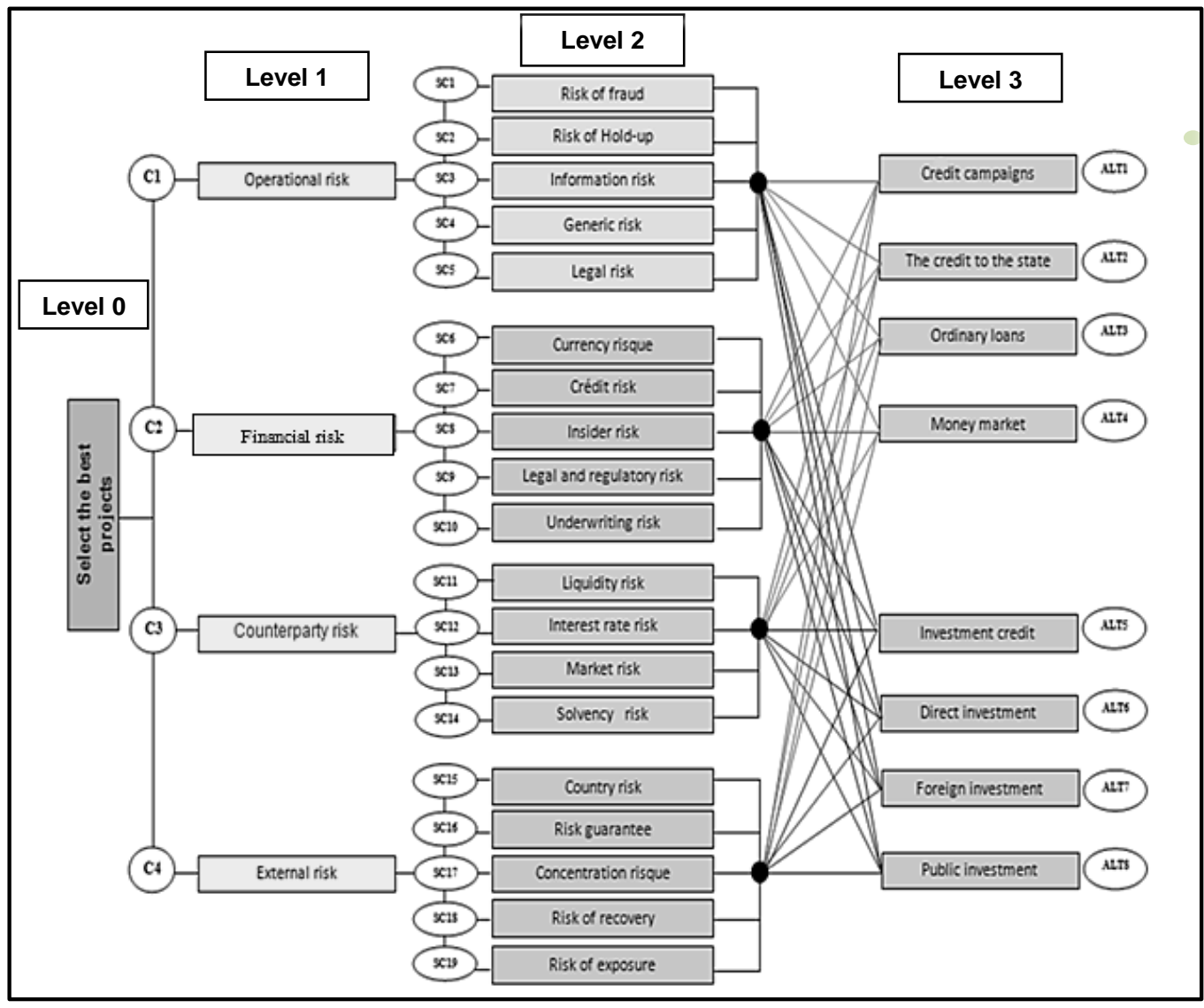

Source: Own elaboration. 
The basic elements of the PROMETHEE method were introduced by JeanPierre Brans in 1982 [3]. It was later developed and implemented by Brans and his colleagues $[4,5,6]$, including extensions such as GAIA.

PROMETHEE has particular application in decision making, and is used around the world in a wide variety of decision scenarios, in fields such as business, governmental institutions, transportation, healthcare and education. We first of all present the problem analysed with the PROMETHEE method. The first result obtained with AHP was used then used as preferences data for the PROMETHEE method. The final results are then analysed.

The problem shown in Figure 1 was analysed using the Multicriteria Decision Method PROMETHEE (Preference Ranking Organization Method for Enrichment Evaluations). PROMETHEE rests on pairwise comparisons of alternatives on every criterion $[3,4,5,6]$. It associates with each criterion, $\mathrm{j}$, a relation $\operatorname{Pj}(a, b)$ reflecting the preference for alternative a relative to alternative $b$ on criterion $\mathrm{j}$. The relation $P j$ contains all available information about the preferences of the decision maker on the criterion $\mathrm{j}$.

Figure 2

Preference Function: "Usual" Form

$$
\begin{gathered}
\forall(a, b), \forall j \text { (Criterion) }: P_{j}(a, b) \\
d_{j}(a, b)=f_{j}(a)-f_{j}(b) \\
\mathrm{H}(d)= \begin{cases}0 & d=0 \\
1 & |d|>0\end{cases}
\end{gathered}
$$

$H(d)$ : Preference Function where $f$ represents the ratings. The form of the graph represents the case where $d$ is positive.

Source: Own elaboration.

The PROMETHEE method allows decision makers to choose one type of criterion from several forms of criteria. Because this problem includes a lot of sub-criteria, we simplify the analysis by choosing the simplest form ("usual" form) of criterion, in which the value of $\operatorname{Pj}(\mathrm{a}, \mathrm{b})$ reflects whether alternatives a and $\mathrm{b}$ are judged as different. In Figure 2, the function $\mathrm{H}$ (with no parameters) reflects preference: whenever there is a difference, $d$, between the ratings of alternatives a and $b, H(d)=1$; if there is no difference, $d=0$, and $H(0)=0$, and the decision maker is indifferent. This criterion form implies that if one 
alternative is better than another, the best one is preferred to the other and if there is no difference between two alternatives the decision maker is indifferent. This function reflects the general case including Maximizing and Minimizing criteria. For our problem, all criteria are minimised because all risks types have to be reduced.

Table 2 below shows the weight values of the four criteria $\left(\mathrm{C}_{1}-\mathrm{C}_{4}\right)$ and the 19 sub-criteria (SC1 - SC19) in the grey columns called Weights and Weights Performance criterion. These weights were obtained in an earlier analysis using the AHP method [7]. The final values (last column) were obtained as the product of the weights of the corresponding criterion and sub-criterion.

$$
\text { Product }=C_{i} \times \sum_{i=1}^{n} S C_{i}
$$

$C_{i}$ :Criteria weigths

$S C_{i}:$ Sub criteria weigths

Table 2

Criteria Weight

\begin{tabular}{|c|c|c|c|c|c|c|}
\hline & Criteria $C_{i}$ & Weights & & Sub criteria (SCi) & $\begin{array}{l}\text { Wights } \\
\text { Performance }\end{array}$ & $\begin{array}{l}\text { Product of } \\
\text { Weights } \\
\text { rounded to } 2\end{array}$ \\
\hline $\mathrm{C}_{1}$ & Operational risk & [0.434] & $\begin{array}{l}\mathrm{SC}_{1} \\
\mathrm{SC}_{2} \\
\mathrm{SC}_{3} \\
\mathrm{SC}_{4} \\
\mathrm{SC}_{5}\end{array}$ & $\begin{array}{l}\text { Risk of fraud } \\
\text { Risk of Hold Up } \\
\text { Information risk } \\
\text { Generic risk } \\
\text { Legal risk }\end{array}$ & $\begin{array}{l}{[0.126]} \\
{[0.606]} \\
{[0.141]} \\
{[0.075]} \\
{[0.052]}\end{array}$ & $\begin{array}{l}{[0.06]} \\
{[0.26]} \\
{[0.06]} \\
{[0.03]} \\
{[0.02]}\end{array}$ \\
\hline $\mathrm{C}_{2}$ & Financial risk & {$[0.366]$} & $\begin{array}{l}\mathrm{SC}_{6} \\
\mathrm{SC}_{7} \\
\mathrm{SC}_{8} \\
\mathrm{SC}_{9} \\
\mathrm{SC}_{10}\end{array}$ & $\begin{array}{l}\text { Currency risk } \\
\text { Credit risk } \\
\text { Insider risk } \\
\text { Legal and regulatory risk } \\
\text { Underwriting risk }\end{array}$ & $\begin{array}{l}{[0.194]} \\
{[0.417]} \\
{[0.089]} \\
{[0.163]} \\
{[0.137]}\end{array}$ & $\begin{array}{l}{[0.07]} \\
{[0.15]} \\
{[0.03]} \\
{[0.06]} \\
{[0.05]}\end{array}$ \\
\hline $\mathrm{C}_{3}$ & Counterparty risk & {$[0.128]$} & $\begin{array}{l}\mathrm{SC}_{11} \\
\mathrm{SC}_{12} \\
\mathrm{SC}_{13} \\
\mathrm{SC}_{14}\end{array}$ & $\begin{array}{l}\text { Liquidity risk } \\
\text { Interest rate risk } \\
\text { Market risk } \\
\text { Solvency risk }\end{array}$ & $\begin{array}{l}{[0.238]} \\
{[0.514]} \\
{[0.133]} \\
{[0.115]}\end{array}$ & $\begin{array}{l}{[0.03]} \\
{[0.06]} \\
{[0.02]} \\
{[0.02]}\end{array}$ \\
\hline $\mathrm{C}_{4}$ & External risk & {$[0.072]$} & $\begin{array}{l}\mathrm{SC}_{15} \\
\mathrm{SC}_{16} \\
\mathrm{SC}_{17} \\
\mathrm{SC}_{18} \\
\mathrm{SC}_{19}\end{array}$ & $\begin{array}{l}\text { Country risk } \\
\text { Risk guarantee } \\
\text { Concentration risk } \\
\text { Risk of recovery } \\
\text { Risk exposure }\end{array}$ & $\begin{array}{l}{[0.489]} \\
{[0.202]} \\
{[0.155]} \\
{[0.091]} \\
{[0.063]}\end{array}$ & $\begin{array}{l}{[0.04]} \\
{[0.02]} \\
{[0.01]} \\
{[0.01]} \\
{[0.01]}\end{array}$ \\
\hline
\end{tabular}

Source: Own elaboration.

The final result that we want to have, we must determine the total order of the eight alternatives, giving the less risky alternative as the first one and the more risky one as the last alternative of the total order. In order to achieve this objective we combine the use of PROMETHEE with AHP. The advantage of such a combination is to process is two steps. First we valuate the weights of all criteria and alternatives and then we rank them. 


\section{ESTABLISH COMPARISONS BY PAIR OF STUDIED ALTERNATIVES}

This step consists in the pairwise comparisons of the eight (08) alternatives symbolized by $\mathrm{ALT}_{\mathrm{i}}$ abbreviation, located on the third level, relatively to each sub-criterion SC1 to SC19. The judgment matrix of eight (08) alternatives is determined such as:

$\mathbf{A L T}_{1}$ : Credits campaigns, $\mathbf{A L T}_{2}$ : The state credits, $\mathbf{A L T}_{3}$ : Ordinary loans,

$\mathbf{A L T}_{\mathbf{4}}$ : Money Market, $\mathbf{A L T}_{\mathbf{5}}$ : Credit Investment, $\mathbf{A L T}_{\mathbf{6}}$ : Direct Investment,

$\mathbf{A L T}_{7}$ : Foreign Investment, $\mathbf{A L T}_{\mathbf{8}}$ : Public Investment.

We applied the same procedure as before for pairwise comparisons of the eight (08) alternatives symbolized by a $\mathrm{ALT}_{\mathrm{i}}$ abbreviation, located on the third level of our model, next to the sub-criteria to be located on the upper level compared to SC1 to SC19. The Table 3 called "table of judging criteria" gives an idea of all these comparisons for the first criteria "Operational Risk".

Table 3

Table of judging criteria

\begin{tabular}{|c|c|c|c|c|c|c|c|c|c|}
\hline $\begin{array}{l}\text { Pairwise comparaison } \\
\text { of alternatives }\end{array}$ & 莺 离 & 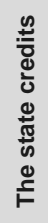 & 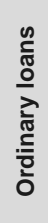 & 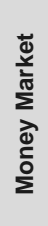 & 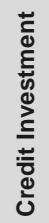 & 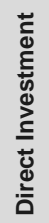 & 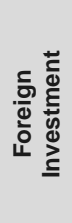 & 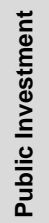 & Complete priority \\
\hline Credits campaigns & 1 & 3 & 3 & 3 & 4 & 4 & 4 & $1 / 7$ & 0,20 \\
\hline The state credits & $1 / 3$ & 1 & 3 & 4 & 3 & 4 & 4 & $1 / 3$ & 0,17 \\
\hline Ordinary loans & $1 / 3$ & $1 / 3$ & 1 & 2 & 2 & 2 & 2 & $1 / 3$ & 0,09 \\
\hline Money Market & $1 / 3$ & $1 / 4$ & $1 / 2$ & 1 & 2 & 2 & 2 & $1 / 3$ & 0,08 \\
\hline Credit Investment & $1 / 4$ & $1 / 3$ & $1 / 2$ & $1 / 2$ & 1 & 2 & 2 & $1 / 4$ & 0,06 \\
\hline Direct Investment & $1 / 4$ & $1 / 4$ & $1 / 2$ & $1 / 2$ & $1 / 2$ & 1 & 3 & $1 / 4$ & 0,05 \\
\hline Foreign Investment & $1 / 4$ & $1 / 4$ & $1 / 2$ & $1 / 2$ & $1 / 2$ & $1 / 3$ & 1 & $1 / 4$ & 0,04 \\
\hline Public Investment & 7 & 3 & 3 & 3 & 4 & 4 & 4 & 1 & 0,31 \\
\hline
\end{tabular}

Source: Own elaboration.

\section{DETERMINE THE PERFORMANCE OF THE ALTERNATIVES RELATIVELY TO THE SUb-CRITERIA}

The next step consists in determining the alternative performance relatively to all sub-criteria located at the second level. Figure 3 shows the alternatives weight, as Figure 4 shows the sub-criteria weight relatively to the four criteria. 
Figure 3

Alternative Weight

\begin{tabular}{l|l|} 
ALT1 & 0,20 \\
ALT2 & 0,17 \\
ALT3 & 0,09 \\
ALT4 & 0,08 \\
ALT5 & 0,06 \\
ALT6 & 0,05 \\
ALT7 & 0,04 \\
ALT8 & 0,31
\end{tabular}

Source : BRANS, J.P., MARESCHAL, B. and VINCKE, P. (1984). "PROMETHEE: A new family of outranking methods in multicriteria analysis". Operational Research. North-Holland, Amsterdam, pp. 477. 490

Figure 4

Sub-criteria Weight relatively to each criteria

Risk of fraud
Risk of hold-up
Information risk
Generic risk
Legal risk
Risk of change
crédit risk
Risk Insider
Legal and regulatory risk
Underwriting risk
Liquidity risk
Risk of in interest rates
Market risk
Solvency risk
Country risk
Risk guarantee
Concentration risk
Risk of recovery
Risk of exposure

\begin{tabular}{|c|c|c|c|c|}
\hline $\mathrm{SC}_{1}$ & 0.06 & 0 & 0 & 0 \\
\hline $\mathrm{SC}_{2}$ & 0.26 & 0 & 0 & 0 \\
\hline $\mathrm{SC}_{3}$ & 0.06 & 0 & 0 & 0 \\
\hline $\mathrm{SC}_{4}$ & 0.03 & 0 & 0 & 0 \\
\hline $\mathrm{SC}_{5}$ & 0.02 & 0 & 0 & 0 \\
\hline $\mathrm{SC}_{6}$ & 0 & 0.07 & 0 & 0 \\
\hline $\mathrm{SC}_{7}$ & 0 & 0.15 & 0 & 0 \\
\hline $\mathrm{SC}_{8}$ & 0 & 0.03 & 0 & 0 \\
\hline $\mathrm{SC}_{9}$ & 0 & 0.06 & 0 & 0 \\
\hline $\mathrm{SC}_{10}$ & 0 & 0.05 & 0 & 0 \\
\hline $\mathrm{SC}_{11}$ & 0 & 0 & 0.03 & 0 \\
\hline $\mathrm{SC}_{12}$ & 0 & 0 & 0.06 & 0 \\
\hline $\mathrm{SC}_{13}$ & 0 & 0 & 0.02 & 0 \\
\hline $\mathrm{SC}_{14}$ & 0 & 0 & 0.02 & 0 \\
\hline $\mathrm{SC}_{15}$ & 0 & 0 & 0 & 0.04 \\
\hline $\mathrm{SC}_{16}$ & 0 & 0 & 0 & 0.02 \\
\hline $\mathrm{SC}_{17}$ & 0 & 0 & 0 & 0.01 \\
\hline $\mathrm{SC}_{18}$ & 0 & 0 & 0 & 0.01 \\
\hline $\mathrm{SC}_{19}$ & 0 & 0 & 0 & 0.01 \\
\hline
\end{tabular}

Source: Own elaboration.

The alternative weight was introduced (ALT1 to ALT8) in each corresponding line. Determining a value in the cell is obtained by the weight of product subcriteria (SC1 to SC19) column in relation to the different weight of the alternatives that are currently online. 


\section{Table 4}

Integration of weight alternatives in line by line

\begin{tabular}{|lllllllllllllllllllll|}
\cline { 2 - 3 } & $\mathbf{S C}_{1}$ & $\mathbf{S C}_{2}$ & $\mathbf{S C}_{3}$ & $\mathbf{S C}_{4}$ & $\mathbf{S C}_{5}$ & $\mathbf{S C}_{6}$ & $\mathbf{S C}_{7}$ & $\mathbf{S C}_{8}$ & $\mathbf{S C}_{9}$ & $\mathbf{S C}_{10}$ & $\mathbf{S C}_{11}$ & $\mathbf{S C}_{12}$ & $\mathbf{S C}_{13}$ & $\mathbf{S C}_{14}$ & $\mathbf{S C}_{15}$ & $\mathbf{S C}_{16}$ & $\mathbf{S C}_{17}$ & $\mathbf{S C}_{18}$ & $\mathbf{S C}_{19}$ \\
& 0.06 & 0.26 & 0.06 & 0.03 & 0.02 & 0.07 & 0.15 & 0.03 & 0.06 & 0.05 & 0.03 & 0.06 & 0.02 & 0.02 & 0.04 & 0.02 & 0.01 & 0.01 & 0.01 \\
\hline ALT1 & 0.20 & 0.20 & 0.20 & 0.20 & 0.20 & 0.20 & 0.20 & 0.20 & 0.20 & 0.20 & 0.20 & 0.20 & 0.20 & 0.20 & 0.20 & 0.20 & 0.20 & 0.20 & 0.20 \\
ALT2 & 0.17 & 0.17 & 0.17 & 0.17 & 0.17 & 0.17 & 0.17 & 0.17 & 0.17 & 0.17 & 0.17 & 0.17 & 0.17 & 0.17 & 0.17 & 0.17 & 0.17 & 0.17 & 0.17 \\
ALT3 & 0.09 & 0.09 & 0.09 & 0.09 & 0.09 & 0.09 & 0.09 & 0.09 & 0.09 & 0.09 & 0.09 & 0.09 & 0.09 & 0.09 & 0.09 & 0.09 & 0.09 & 0.09 & 0.09 \\
ALT4 & 0.08 & 0.08 & 0.08 & 0.08 & 0.08 & 0.08 & 0.08 & 0.08 & 0.08 & 0.08 & 0.08 & 0.08 & 0.08 & 0.08 & 0.08 & 0.08 & 0.08 & 0.08 & 0.08 \\
ALT5 & 0.06 & 0.06 & 0.06 & 0.06 & 0.06 & 0.06 & 0.06 & 0.06 & 0.06 & 0.06 & 0.06 & 0.06 & 0.06 & 0.06 & 0.06 & 0.06 & 0.06 & 0.06 & 0.06 \\
ALT6 & 0.05 & 0.05 & 0.05 & 0.05 & 0.05 & 0.05 & 0.05 & 0.05 & 0.05 & 0.05 & 0.05 & 0.05 & 0.05 & 0.05 & 0.05 & 0.05 & 0.05 & 0.05 & 0.05 \\
ALT7 & 0.04 & 0.04 & 0.04 & 0.04 & 0.04 & 0.04 & 0.04 & 0.04 & 0.04 & 0.04 & 0.04 & 0.04 & 0.04 & 0.04 & 0.04 & 0.04 & 0.04 & 0.04 & 0.04 \\
ALT8 & 0.31 & 0.31 & 0.31 & 0.31 & 0.31 & 0.31 & 0.31 & 0.31 & 0.31 & 0.31 & 0.31 & 0.31 & 0.31 & 0.31 & 0.31 & 0.31 & 0.31 & 0.31 & 0.31 \\
\hline
\end{tabular}

Source: Own elaboration.

In our research the AHP method is used for the first steps of our proposed methodology, while PROMETHEE is used to obtain the final ranking of alternatives. The different weights obtained from the performance criteria illustrated by Table 5 are used in the calculations of PROMETHEE, and alternatives priorities are determined on the basis of these weights.

Table 5

Weights Summary

\begin{tabular}{|c|c|c|c|c|c|c|c|c|}
\hline & ALT1 & ALT2 & ALT3 & ALT4 & ALT5 & ALT6 & ALT7 & ALT8 \\
\hline Weights & 0.2 & 0.17 & 0.09 & 0.08 & 0.06 & 0.05 & 0.04 & 0.31 \\
\hline
\end{tabular}

Source: Own elaboration.

\section{RESULTS}

The analysis is based on the 19 sub-criteria. All eight alternatives are scored on a continuous scale $[0,1]$. The score of each alternative is determined from a first analysis conducted with AHP (see [7]).

The results of the PROMETHEE I analysis are shown in Figures 6 that shows the calculated preference flow of all alternatives. It is easy to see that ALT7: Foreign Investment is the best and that ALT8: Public Investment is the worst.

These results show that by combining two MCDA methodologies we can obtain opposite results. The first results obtained with AHP show that ALT7 is the worst and ALT8 is the best and combining these first results with PROMETHEE we obtained the contrary. We can see that, the way, how the used methodologies are combined, have a very high importance on the final result. Other studies could be done in order to see if this main result is the main using first PROMETHEE and then AHP. 
Figure 5

Partial Performance Matrix

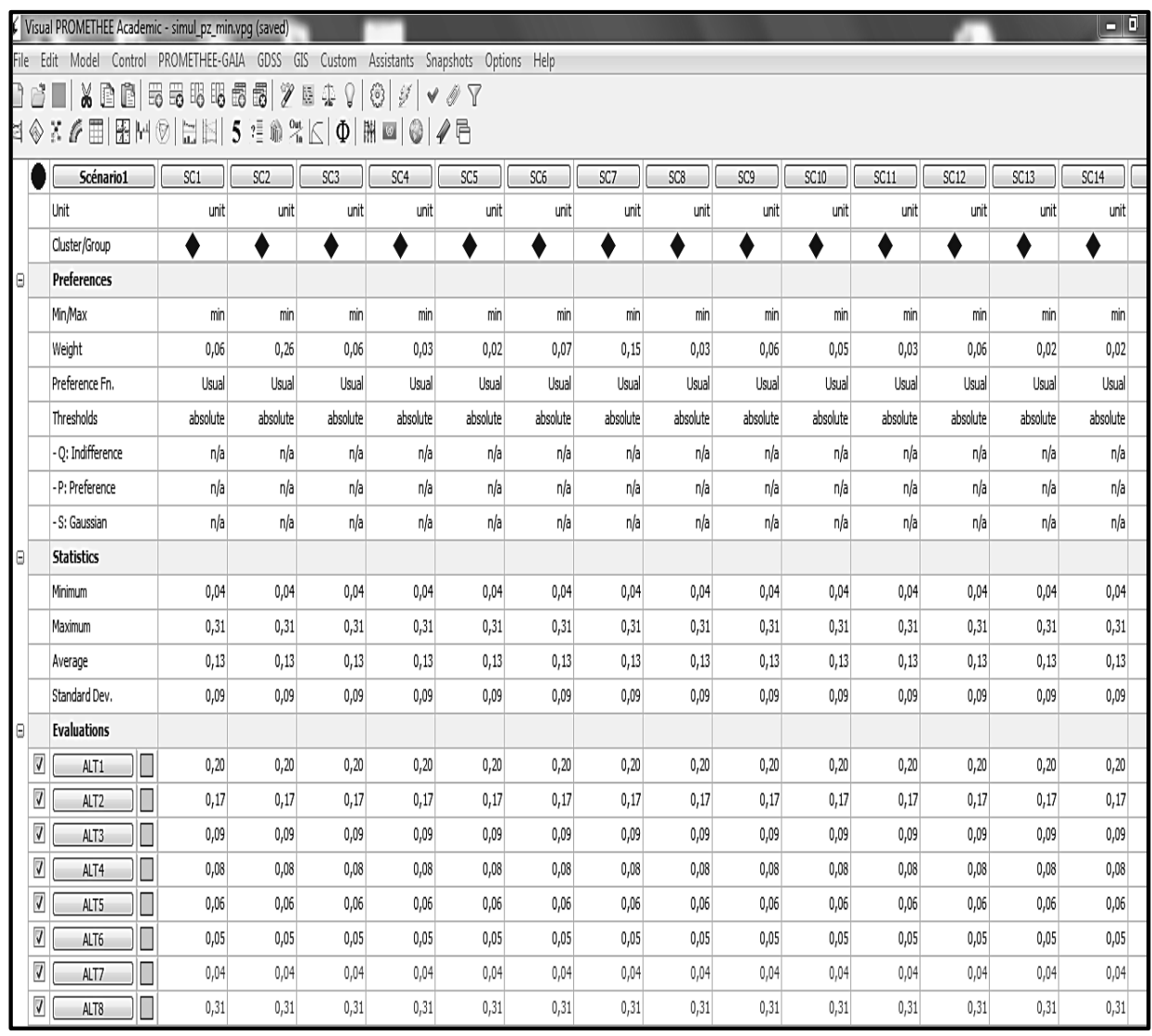

Source: Own elaboration.

Figure 6

Preference Flow

\begin{tabular}{|l|rrr|}
\hline \multicolumn{1}{|l}{ Preference Flows } \\
\hline \hline
\end{tabular}

Source: Own elaboration. 


\section{CONCLUSION}

This work aimed to analyze financial investments for banks or financial institutions using the Multi-Criteria Method PROMETHEE. It employs results obtained in a previous analysis conducted with the AHP method [7].

One limitation of this work is that the preferences were evaluated by only one individual, an individual whose expertise was based primarily on a literature review. Therefore these preferences, and the conclusions we drew from them, should be considered as tentative. In order to validate the proposed methodology, we intend to obtain real preferences from risk managers in realworld banking institutions. This study shows the importance of managing the future risks. This kind of study is very interesting in order to evaluate future risks and support decision makers for their choices. We can consider that bank institutions could face in the future to risks related to Information Technologies: hacking and information system security problems, customers' privacy protection etc. Researches in these areas must be improved in order to deal with these potential risks.

\section{BIBLIOGRAPHY REFERENCES}

KEREBEL, P. (2009). «Management des risques, inclus secteur banque et assurance». Edition d'organisation EYROLLES, ISBN : 978-2-212-54308-7.

CHELLY, D. and SEBELOUE, S. (2014). «Les métiers du risque et du contrôle dans la Banque», Optimind winter, Observatoire des métiers.

BRANS, J.P. (1982). «L'ingénierie de la décision; Elaboration d'instruments d'aide à la décision. La méthode PROMETHEE», in Nadeau R et Landry M (Eds), L'aide à la décision: Nature, Instruments et Perspectives d'Avenir. Presses de I'Université Laval, Québec, Canada, pp. 183-213.

BRANS, J.P. and MARESCHAL, B. (1994). "The PROMCALC and GAIA decision support system for MCDA". Decision Support System, vol. 12, pp. 297-310.

BRANS, J.P., MARESCHAL, B. and VINCKE, P. (1984). "PROMETHEE: A new family of outranking methods in multicriteria analysis". Operational Research. North-Holland, Amsterdam, pp. 477-490.

BRANS, J.P., VINCKE, P. and MARESCHAL, B. (1986). "How to Select And How to Rank Projects: The PROMETHEE Method". European Journal of Operational Research, vol. 24, pp. 228-238.

RAKOTOARIVELO, J.B., ZARATE, P. and J.P. RAZAFIMANDIMBY, J.P. (2015). "Multicriteria Decision Analysis for banks risks evaluation" (poster), In : International Conference on Decision Support Systems Technologies (ICDSST 2015), Belgrade, Serbia, 27/05/2015-29/05/2015, Boris Delibasic, Fatima Dargam, Pascale Zaraté, Jorge Hernandez, Shaofeng Liu (Eds.), University of Belgrade, pp. 55. 